原算

成人鼠径へルニア手術における笑気ガス麻酔併用局所麻酔の有用性

新潟県厚生連系魚川総合病院外科, 富山医科薬科大学第 2 外科*

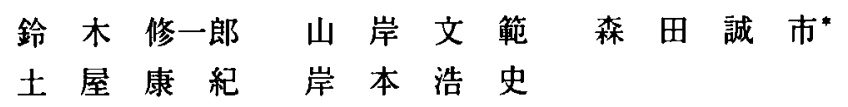

局所麻酔下での成人鼠径ヘルニア手術において, 笑気ガス麻醉を併用し, 術中の疼痛, 不安, 局麻剤中毒の問題において, 果たしてその併用が有用か否か検討した. 対象は再 発嵌頓例を除いた成人鼠径ヘルニア 96 例で局所麻醉単独 64 例, 笑気併用 32 例である. 手術は全例に可能であった，術中疼痛は笑気併用により疼痛の緩和が見られ，WongBakerフェイススケール0，1，2が 90.6\% と局麻単独群 $80 \%$ に比べ良好であった. ま た術中鎮痛剂の追加使用㫣 $(1.9 \pm 6.3 \mathrm{mg}$ vs $7.3 \pm 10.0 \mathrm{mg})$, 追加頻度 $(9.4 \%$ vs $40.6 \%)$ も 局麻単独群に比べ少なく、術中疼痛の改善を示していた，両群とも術中の呼吸循環動態 は安定し，局麻郕中毒の問題もなく，術中の管理は容易であった。術中の不安は程度の 差はあるものの $33 \%$ が感じており，不安に対する対策が必要である. 笑気がス麻醉併用 により術中疼痛, 不安の楥和, 局麻剤, 鎮痛剂使用量の減量, 局麻剤中毒の予防につな がり,より有用である.

索引用語：鼠径ヘルニア，局所麻醉，笑気ガス麻醉

\section{はじめに}

笑気ガス麻醉は蒾科の治療や小児の傷の䋖合に用い られ”，良好な結果を得ている. 今回, 局所麻醉下での 成人鼠径ヘルニア手術に拉いて，笑気ガス麻酔を併用 し, 術中の疼痛, 不安, 局麻剂中毒の問題において, 果たしてその併用が有用か否か検討したので報告す る.

\section{対象と方法}

対象は 1995 年 7 月より 1998 年 9 月までに局所麻醉 下に手術を行った成人鼠径へルニアのうち再発および 嵌頓例を除いた 96 例で, 局所麻酔単独で行った局麻単 独群 64 例，笑気ガス麻醉併用局所麻酔で行った併用群 32 例である. 局所麻酔による手術は1995 年 7 月より 開始し，1996年1月からは再発，嵌頓例を除き first choiceで行った.ささらに1998 年1月からは笑気ガス 麻酔の併用を開始した，笑気ガス麻酔は酸素 $4 \mathrm{l} / \mathrm{min}$, 笑気 $21 / \mathrm{min}$ で笑気の濃度は $33 \%$ である。

局所麻酔の方法は局所浸潤麻酔で epinephrine 加 1 \% lidocaine および $0.5 \%$ bupivacaineを $1 ： 1$ に混合 し,また初めの $10 \mathrm{ml}$ に sodium bicarbonate $1 \mathrm{mEq}$
を混合し使用した。なお手術開始時には pentazocine $30 \mathrm{mg}$ を静注した(表 1 )。

術後管理は両群とも術前日に入院し手術を行った。 歩行制限はせず，食事は当日夕食より開始した。退院 は術後第 4 病日以内とした.

\section{結 果}

1）対象症例の内訳

局麻単独群の内訳は男性 54 例，女性 10 例で年齢は

\section{表 1 使用薬㓣および方法}

1. 使用薬凨：epinephrine 加 $1 \%$ lidocaine および $0.5 \%$ bu pivacaine $1: 1$ に混合し使用. 初めの $10 \mathrm{ml}$ に sodium bicarbonate $1 \mathrm{mEq}$ を混合し使用.

2. 方法

1) 皮下組織への注入：皮切予定線に治い的 $4 \mathrm{ml}$ 注入.

2) 皮内組織への注入：皮切予定線に沿い約 $3 \mathrm{ml}$ 注入.

3）皮下組織深居への注入：皮切予定線に沿い $2 \mathrm{~cm}$ 間隔 で皮犕に垂直に注射針を刺入し $2 \mathrm{ml}$ ずつ計的 $8 \mathrm{ml}$ 注 入.

4）外腹斜等腱膜への注入：切離予定線に沿い的 $3 \mathrm{ml}$ 注入.

5）内鼠径輪付近への注入：鼠径管解放後挙等等より精索 背側に $1 \mathrm{ml}$ さらに内鼠径制外㑡に $1 \mathrm{ml}$ 注入. 尚、滅張切開の際は腹直筋前鞘に注入. 
平均 64.3 歳. 直接型 6 例, 間接型 58 例で, その術式は Potts' repair 2 例, Marcy 法 20 例. ilopubic tract repair 41 例, Mesh plug 法 1 例であった．併用群は男性 27 例，女性 5 例で, 年齢は平均 66.7 嵗. 直接型 7 例, 間接型 25 例で，その術式は Marcy 法 9 例，iliopubic tract repair 17 例, Mesh plug 法 6 例であった. 背景因 子は術式に差を認めた以外，2 群間に差はなかった(表 2).

\section{2）術中疼痛}

術中疼痛についてWong-Baker フェイススケール" を用いアンケート調查を行った，小児を対象として開 発された疼痛スケールで，絵の表情を見て解答するも のである． 0 が a very smiling face， 5 が a sad, teaful faceの6段階に分類したものである.

局所麻酔単独での手術は 80\% が Wong-Baker フェ イススケール1ないし 2 の痛みで，比較的楽に手術が 受けられたと感じている。しかし，20\%は強い痛みを 感じており，より良好な術中疼痛のコントロールを行 うため笑気によるガス麻酔の併用を行った。笑気ガス 麻酔併用により改善を認め，併用群では 0 が $38 \% ， 1$ が $38 \% ， 2$ が $16 \%$ と0，1，2で $92 \%$ をしめ，局麻单 独群に比べ有意に術中疼痛の軽減を認めた（図 1).

\section{3）手術時間，局麻忶，鎮痛剤の使用量}

手術時間は局麻単独群 79.3 分, 併用群 82.0 分と差は なかった．局麻敦の使用量は局麻単独群で $30.5 \mathrm{ml}$, 併 用群で $28.4 \mathrm{ml}$ と局麻单独群に比べ少ない傾向にあっ た. 鎮痛㓮の使用量は局麻単独群 $35.7 \mathrm{mg}$, 併用群 31.4 $\mathrm{mg}$ と併用群で少なく，また追加使用量はそれぞれ 7.3 $\mathrm{mg}, 1.9 \mathrm{mg}$, 追加頻度は 40.6\%, 9.4\% と併用群でいず れも局麻単独群に比べ有意に少なく, 術中疼痛の改善 を示している(表3).

表 2 鼣径ヘルニア对象症例

\begin{tabular}{l|c|c|c}
\hline & 局麻単独 & 局麻 +笑気 & $\mathrm{p}$ value \\
\hline 症例数 & 64 & 32 & - \\
\hline 性別 男性 : 女性 & $54: 10$ & $27: 5$ & n.s. \\
\hline 年齡 & $64.3 \pm 15.0$ & $66.7 \pm 10.8$ & n.s. \\
\hline 型 直接 : 間接 & $6: 58$ & $7: 25$ & n.s. \\
\hline 術式 & & & \\
Potts repair & 2 & 0 & \\
Marcy repair & 20 & 9 & p $<0.01$ \\
Iliopubic tr. repair & 41 & 17 & \\
Mesh plug & 1 & 6 & \\
\hline
\end{tabular}

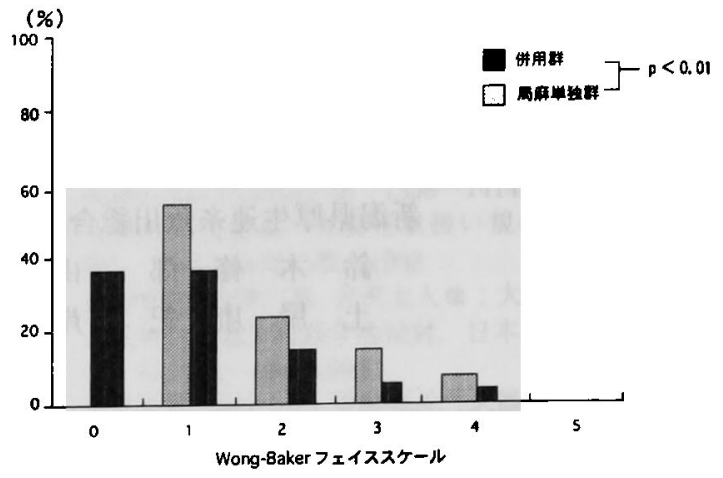

图 1 術中疼痛

表 3 手術時間, 麻酥隹使用量

\begin{tabular}{|c|c|c|c|}
\hline & 局麻単独 & 局麻＋笑気 & $p$ value \\
\hline 手術時間 (分) & $79.3 \pm 17.5$ & $82.0 \pm 25.8$ & n.s. \\
\hline $\begin{array}{r}\text { 局麻能使用量 } \\
(\mathrm{ml}) \\
(\mathrm{ml} \mathrm{kg})\end{array}$ & $\begin{array}{l}30.5 \pm 5.6 \\
0.56 \pm 0.12\end{array}$ & $\begin{array}{l}28.4 \pm 5.1 \\
0.52 \pm 0.09\end{array}$ & $\begin{array}{c}\mathrm{p}=0.07 \\
\text { n.s. }\end{array}$ \\
\hline $\begin{array}{l}\text { 鎮捅郕 } \\
\text { 使用量 (mg) } \\
\text { 追加使用量 }(\mathrm{mg}) \\
\text { 追加頻度 }\left(\mathrm{o}_{\mathrm{o}}\right) \\
1 \text { 回 } \\
2 \text { 回 }\end{array}$ & $\begin{array}{c}35.7 \pm 9.1 \\
7.3 \pm 10.0 \\
40.6 \\
2364 \\
3: 64\end{array}$ & $\begin{array}{c}31.4 \pm 7.1 \\
1.9 \pm 6.3 \\
9.4 \\
2 \times 32 \\
132\end{array}$ & $\begin{array}{l}p<0.05 \\
p<0.01 \\
p<0.01\end{array}$ \\
\hline
\end{tabular}

\section{4）術中循環動態}

術中循環動態の変化は局麻単独群で血圧の低下を 1 例に認めたが，昇圧剤の必要はなく，輸液速度を速め ることにより改善した．2群とも術中循環動態は安定 し，術中管理は容易であった（表 4)。

\section{5）術後合併症}

術後合併症は浸出液貯留などの創合併症, 虚血性睪 丸炎などを認めたが, 2 群間に有意差はなかった.また 術後の愁訴では局麻単独群で導尿を必要とする頻度が 64 例中 11 例 17.2\% と多く認められた（表 5).

\section{6) 術中の不安}

術中の不安について笑気ガス麻醉併用例 18 例に了 ンヶート調查を行った，不安がなかったもの 9 例，時 に不安を感じたもの 5 例, 強い不安を感じたもの1例， 回答がなかったもの 3 例であった，術中疼痛との間に 有意な相関関係は認めなかった（表 6).

\section{7）入院期間}

入院期間は術後鎮痛剤の使用が術後第 4 病日以降な いことから，1996 年 12 月より第 4 病日以内の退院と 


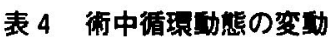

\begin{tabular}{c|c|c|c}
\hline & 局麻単独 & 局麻 +笑気 & $\mathrm{p}$ value \\
\hline $\begin{array}{c}\text { 血圧低下 } \\
(\leqq 90 \mathrm{mmHg})\end{array}$ & $1.6 \%$ & $0 \%$ & n.s. \\
\hline 昇圧剂の使用 & 0 & 0 & n.s. \\
\hline $\begin{array}{c}\text { 徐脈 } \\
(\leqq 60 \mathrm{~min})\end{array}$ & 0 & 0 & n.s. \\
\hline
\end{tabular}

表 5 術後合併症および愁铩

\begin{tabular}{c|c|c|c}
\hline & 局麻単独 & 局麻 + 笑気 & p value \\
\hline 畣合併症 & $6.3 \%$ & $9.4 \%$ & n.s. \\
\hline 虚血性睪丸炎 & 1.6 & 0 & n.s. \\
\hline 便秘 & 17.2 & 31.3 & n.s. \\
\hline 導尿 & 17.2 & 0 & $\mathrm{p}<0.01$ \\
\hline
\end{tabular}

表 6 衍中不安感と疼痛

\begin{tabular}{c|c|c|c|c|c|c|c}
\hline \multirow{2}{*}{ 術中の不安感 } & \multirow{2}{*}{ 例数 } & \multicolumn{6}{|c}{ 術 中 疼 痛 } \\
\cline { 3 - 9 } & & 0 & 1 & 2 & 3 & 4 & 5 \\
\hline 不安なし & 918 & 3 & 3 & 2 & 0 & 1 & 0 \\
\hline 時に不安あり & 518 & 2 & 2 & 1 & 0 & 0 & 0 \\
\hline 強い不安 & 118 & 0 & 0 & 1 & 0 & 0 & 0 \\
\hline 回答なし & 318 & 2 & 1 & 0 & 0 & 0 & 0 \\
\hline
\end{tabular}

術中疼痡：Wong-Bakerフェイススケールにて表示

した. 術後入院日数のピークは 1996 年 12 月以前では 8 日間，それ以後では 4 日間と，入院期間の短縮を認 め，経費削減につながっている(图 2).

統計的有意差娭定には分散分析， $\chi^{2}$ test, Student's $\mathrm{t}$ test およびMann-Whitney test を用いた.いずれも p く0.05をもって有意と判定した.

\section{考察}

近年, 成人鼠徍へルニアに对する手術術式の変遷と ともに，全身麻酔から局所麻酔まで種々の麻酔法が選 択されているが，一般には腰椎麻酔で行われている。 しかし, 腰椎麻醉に伴う合併症として術中の spinal shock，咺気，嘔吐が，また術後では脊椎麻醉後後遗症 があり，必ずしも良好な経過をたどるわけではない。 特に，外科医が麻醉管理を行いながら手術をしている 中小規模の病院では, 術中管理の問題は重要である.

当院では 1995 年 7月より局所麻酔にて手術を行い, 良好な結果を得てきだ．しかし，局所麻醉での問題点 は従来より指摘されているように，術中疼痛，および

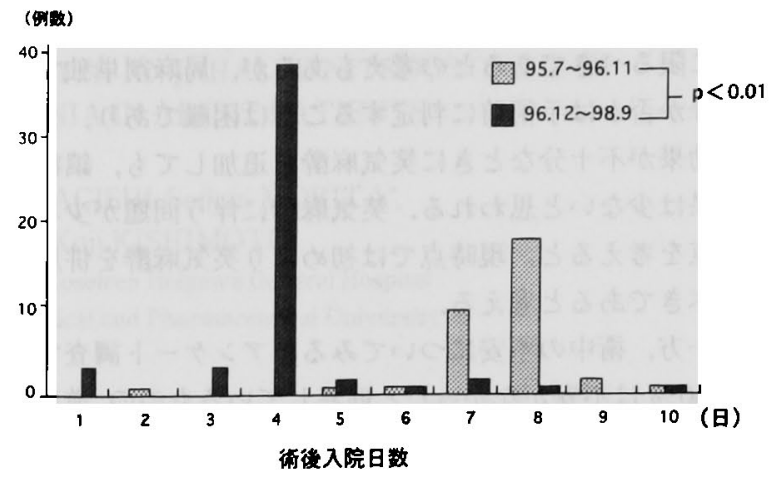

図 2 術後入院日数

不安の問題さらに局麻剂中毒の問題がある.

術中疼痛について局麻剤単独では前回の検討で 88.2 $\%$ \%゙", 今回の検討では $80 \%$ が術中疼痛の程度を Wong-Baker フェイススケール 0, 1，2 と答え, 比較 的楽に手術が受けられたと感じている．反面，20\%は 強い痛みを感じており，より良好な術中疼痛のコント ロールが必要であると思われる，そこで萪科治療で用 いられる笑気ガス麻酔の併用を試みた. 笑気 33\% と低 濃度での笑気ガス麻酔の併用を行った。 その結果, 術 中疼痛の緩和がみられ, Wong-Baker フェイススケー ル $0 ， 1 ， 2$ で $90.6 \%$ と局麻剂単独群 $80 \%$ に比べ改善 を示し、また術中鎮痛唷の使用量, 追加使用量, 追加 頻度の減少がみられ，術中疼痛の改善を示していた。 また，笑気併用群で導尿を必要とする頻度が局麻剂単 独群に比べて有意に少ないことより術中疼痛の軽隇が 関連している可能性が示唆される。

一方，笑気は古く 1844 年 Horace Wellsにより抜歯 に用いられてから ，比較的安全な吸入麻酔薬として， 盛んに用いられている!。笑気は $30 \%$ 以上で軽度鎮痛 作用を認めるが、，一般的には鎮痛効果を得るには 50 \%以上の濃度を必要とする の笑気により鎮痛作用とともに confusion, hallucination, 無意識の暴れ等が起こるとされ ある．しかし，今回，使用した笑気の濃度は $33 \%$ と低 濃度であり，興奮を示す症例はみられなかった。本研 究での手術では術中 pentazocine の使用とあいまっ て，患者は半覚醒の状態であることが多く，呼吸障害 は1例も見られなかった，笑気によるガス麻酔併用の 目的はあくまで局所麻酔の補助である，笑気ガス麻酔 併用による術中の合併症はなく，また鎮痛作用も得ら れており，有用であると思われる。一方，笑気麻酔の 
併用は局麻片単独では十分な鎮痛刘果が得られない場 合に限るべきであるとの考えもあるが，局麻剤単独で 十分か否かは手術前に判定することは困難であり，ま た効果が不十分なときに笑気麻醉を追加しても，鎮痛 効果は少ないと思われる. 笑気麻酔に伴う問題が少な い点を考えると, 現時点では初めより笑気麻酔を併用 すべきであると考える.

一方, 術中の不安についてみるとアンケート調査で は 50\%は不安がなかったと回答しているものの, 逆に 33\%は何らかの不安を感じており, 術中の不安に対す る対策が必要である，今回のアンケート調査では術中 疼痛と不安との関連は見いだされなかったものの, 術 中疼痛のコントロールを十分に出来れば，不安の解消 につながるものと思われる。しかし，局所麻酔での疼 痛は突然の痛みであることが多く，前もって患者に声 をかけることが重要である。また患者個々には医師、

看荽婦の話が聞こえ，それにより安心したり，不安を 感じていた。相瀬”が指摘しているように手術前に十分 局所麻醉について説明すること, 術中極力不安や痛み を与えないこと，痛みがある部位については前もって 麻酔をしておくこと,の他に基本的なことではあるが， 㭧者が手術の進行状況がわかり，また医師，看護婦の 話がよく聞こえており，十分注意する必要がある.

局麻剂は epinephrine 加 $1 \%$ lidocaine および $0.5 \%$

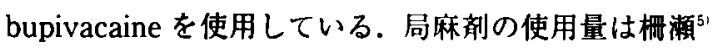
は片側 $50 \mathrm{ml}$ 以下, Amid PK ら $\mathrm{ml}$ と報告をしている.今回の検討では局麻剤単独群で 平均 $30.5 \mathrm{ml}$, 笑気ガス麻醉併用群で平均 $28.4 \mathrm{ml}$ であ $ク$, lidocaine, bupivacaine の極量を超えることはな かった．しかし，局麻滆の吸収速度，投与総量, 血中 の分布, 蛋白結合, 代謝, 排泄など種々の要素により, 局麻剤中毒の可能性はある. その予防のために epinephrine の併用，局麻荗の血管内混入の予防，lido- caine, bupivacaine の併用等により局麻刘中毒の予防 に努めている.

\section{䊅 語}

再発嵌頓例を除いた成人鼠径ヘルニア96 例に対し 局所麻醉にて手術を行った. 局所麻醉での手術は全例 に可能であった. 笑気ガス麻醉の併用により術中疼痛,

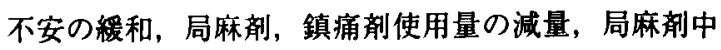
毒の予防につながり，より有用である。

笑気ガス麻醉を併用した局所麻酔は麻醉に伴う影響 が少なく，そのため早期離床が可能であり，入院期間 の短縮, 経費削隇につながる。

\section{文献}

1) Burton JH, Auble TE, Fuchs SM : Effectiveness of $50 \%$ nitrous oxide $/ 50 \%$ oxygen during laceration repair in children. Acad Emerg Med 5 : $112-117,1998$

2) Whaley L. Wong $D$ : Nursing Care of infants and children. ed 3., C.V. Mos by, Missouri, 1987, p 1050

3) Amid PK, Shulman AG, Lichtenstein IL : Local Anesthesia for Inguinal Hernia Repair Step-by. Step Procedure, Annals Surgery 220 : 735-737. 1994

4）舒木修一郎, 吉田 徹, 小野 聡他：成人鼠径へル ニア手術における局所麻醉の有用性. 日臨外会誌 $59: 1507-1511,1998$

5）桐濑信太郎：鼠徍ヘルニア手術のコ\%。臨外 $48: 293-301,1995$

6）稲本 晃: 全身麻醉薬の薬理. 木本誠二監, 現代外 科学体系, vol 2 麻醉, 中山書店, 東京, 1968, p 1546

7) 杉浦良啓: 吸入麻醉法. 後藤幸夫編, 麻醉蘇生科研 修マニュアル, 南山堂, 東京, 1993. p 245一256

8）譛岐美智手：麻醉と救急のために。麻醉科医の使 う薬がわかる本. 広鳥大学医学部森醉・荣生学教 室「麻醉と蘇生」, 公島, 1996, p 103 


\title{
THE USEFULNESS OF LOCAL ANESTHESIA WITH AN INHALED NITROUS OXIDE IN OPERATION FOR INGUINAL HERNIA IN ADULT PATIENTS
}

\author{
Shuichiro SUZUKI, Fuminori YAMAGISHI, Seïchi MORITA*' \\ Yasunori TSUCHIYA and Koji KISHIMOTO \\ Department of Surgery, Niigata-Prefectural Koseiren Itoigawa General Hospital \\ -Second Department of Surgery. Toyama Medical and Pharmaceutical University
}

The purpose of this study is to confirm advantages of using inhaled nitrous oxide with local anesthesia regarding questions of intraoperative pain, anxiety and toxicity of anesthetics when performing surgery for adult inguinal hernia. Ninty-six adult patients with inguinal hernia except reurrent or incarcerated cases who have been operated on under local anesthesia were included in this study. Sixty-four cases underwent operations under local anesthesia only (single group), and 32 cases under local anesthesia with an inhaled nitrous oxide (combined group). All operations were possible in both groups. Additionally used quantities and frequencies of analgesics in combined group during operation have become decrease than those in single group. In both groups the respiratory and hemodynamics were stable and there was no problem of toxicity of anesthetics, so it was easy to control the intraoperative management. Though the severites of intraoperative anxiety were different, $33 \%$ of all patients were unrest. So countermeasures against the anxiety is nececcary. Combined use of inhaled nitrous oxide leads to improving intraoperative pain, anxiety, reduction in dose and frequency of analgesics and prevention of toxicity of local anesthetics. Advantages of using inhaled nitrous oxide with local anesthesia have been demonstrated. 